УДК [378.147:314]:004

Панченко Любов Феліксівна

професор, доктор педагогічних наук, професор кафедри соціології

НТУУ «Київський політехнічний інститут ім. І.Сікорського», м. Київ, Україна

ORCID ID 0000-0002-9979-0625

lubov.felixovna@gmail.com

\title{
ПІДГОТОВКА МАЙБУТНІХ СОЦІОЛОГІВ ДО КОМП'ЮТЕРНОГО АНАЛІЗУ ДЕМОГРАФІЧНИХ ПРОЦЕСІВ І СТРУКТУР
}

\begin{abstract}
Анотація. У сучасному цифровому глобалізованому світі зростає важливість підготовки майбутніх соціологів у галузі демографії й демографічної статистики, яка основана не лише на демографічних теоріях, а й практичному застосуванні нових комп'ютерних засобів i технологій, баз даних і сервісів Інтернету. У статті аналізуються можливості сучасних комп'ютерних засобів щодо аналізу демографічних процесів і структур з метою навчання майбутніх соціологів; обгрунтовується використання середовища R як інструмента аналізу $\mathrm{i}$ графічного представлення демографічних даних;презентується ідея навчання студентів комп'ютерному аналізу даних демографічних досліджень шляхом поєднання використання електронних таблиць Excel, статистичного пакету SPSS, середовища R, яка ілюструється двома прикладами. Перший приклад стосується побудови i порівняння статево-вікової піраміди населення України за різні роки і включає пошук відповідних даних, побудову піраміди стандартними засобами для побудови діаграм Excel; засобом SPSS (ChartBuilder, Histogram, PopulationPyramid), 3 використанням пакету pyramid середовища R. Другий приклад, присвячений розрахункам коефіцієнтів демографічного навантаження дітьми i прабатьками, візуалізації їх динаміки, передбачає знайомство з демографічним паспортом населення України. У статті представлено розроблене методичне забезпечення з навчання студентів-соціологів аналізу демографічних даних, яке містить лекції-презентації з основ роботи в середовищі R та R Studio; лабораторні роботи (коротка теорія, детальні інструкції до виконання, контрольні запитання, завдання до самостійної роботи); масиви даних, які додаються до кожної роботи. Аналізуються дидактичні можливості та шляхи використання вільного сервісу Gapminder, який включає перелік інструментів під загальною назвою «Playwithdata»: бульбашкову діаграму, карти, ранжування, тренди, вікові піраміди; усі вони дозволяють отримати яскраві динамічні візуалізації обраних демографічних показників (залежно від дослідницького питання) за країнами й континентами в часі, що мотивує студентів на додатковий науковий пошук.
\end{abstract}

Ключові слова: комп’ютерний аналіз даних; демографічна статистика;Excel; SPSS; середовище R; інформаційно-комунікаційні технології; Gapminder; студенти-соціологи.

\section{1. ВСТУП}

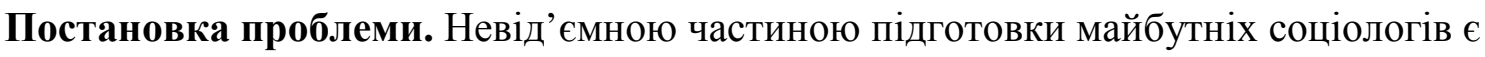
осмислення суті демографічних явищ i проблем, а також оволодіння методами вимірювання й аналізу демографічних процесів і структур. Наряду з вивченням історії становлення демографії як науки, студенти-соціологи з'ясовують зміст джерел демографічної інформації; опановують методи дослідження динаміки чисельності населення, його структури, окремих демографічних процесів; оцінюють та виявляють закономірності демографічних процесів, тощо. Наразі зростає важливість підготовки майбутніх соціологів у галузі демографії та демографічної статистики, яка основана не лише на демографічних теоріях, а й практичному застосуванні нових інструментів дослідження демографічних явищ - комп'ютерних засобів і технологій, баз даних демографічної інформації, сервісів Інтернету. 
Аналіз останніх публікацій. Основи демографії і демографічної статистики представлені у роботах вітчизняних науковців С. Стеценко [2], 3. Пальян [3], I. Прибуткової [4] та ін.

Демографію як просторову соціальну науку, яка має справу з розподіленими в просторі даними,розглядає у своєму аналітичному огляді П. Восс (P. Voss) [1]. Прикладний аналіз просторових даних (Exploratory Spatial Data Analysis) включає теоретичні й методологічні питання аналізу просторово розподілених даних: типи даних, які доступні для просторового аналізу; основні способи їх представлення та аналізу; просторові закономірності.

Останнім часом цікавість науковців різного фаху привертає середовище $\mathrm{R}, 3$ його різноманітністю інструментів для статистичного аналізу й візуалізації даниху різних галузях. Розвиток середовища $\mathrm{R}$, методичні аспекти його застосування представлені у роботах P. Андерсена (R. Andersen), Дж. Фокса (J. Fox) [5] та ін. Р.C. Біванд (R.S. Bivand), Е. Пебезма (E. Pebesma) та B. Го́мез-Рубio(V. Gómez-Rubio) [6] розглядають прикладний аналіз просторових даних за допомогою R.Пакети для обробки демографічних даних, представлення просторової інформації в середовищі $\mathrm{R}$ розроблені зусиллями А. Ламштейна (A.Lamstein) [7], Р. Гиндмана (R. Hyndman) [8],Зака У. Алмквіста (Zack W. Almquist), Юнь Тайн (YunTai), T. Рiффе (T. Riffe) та ін. [9]. Роботи С.Хауба (С.Наub) присвячені обробці даних переписів США [10]. Використання $\mathrm{R}$ для навчання обробки демографічних даних розглядається в роботах К. Камарда (С. Camarda) [11]. Зауважимо, що більшість розробок представлено переважно у вигляді технічної документації до пакетів R, що потребує методичної обробки для навчання студентів-гуманітаріїв.

На жаль, середовище $\mathrm{R}$ не посіло належного місця для навчання студентів обробки демографічних даних. Ми не знайшли такого курсу у програмі вітчизняних вишів, натомість знайшли короткий курс з програмування в R для завдань демографії в Іспанії, у рамках якого для студентів $\mathrm{PhD}$ дослідників Spanish National Research Council розглядаються основні статистики і графіки; розподіли, випадкові числа та ручна оптимізація; генералізовані лінійні моделі, демографічне прогнозування, матрична алгебра та когортний аналіз(https://sites.google.com/site/carlogiovannicamarda). Ще один курс з літньої школи в Барселоні охоплює три сильні сторони R: статистичний аналіз, візуалізацію даних та просторовий аналіз. Перший модуль: «Вступ до $\mathrm{R}$ i базової статистики» представляє маніпулювання даними і базовий статистичний аналіз. Другий модуль «Візуалізація даних і просторовий аналіз» зосереджується на інструментах візуалізації даних, що представлені у пакеті ggplot2 R. Далі студенти навчаються обробляти просторові дані в $\mathrm{R}$, розробляти цифрову картографію і виконувати основні види аналізу просторових даних (http://ced.uab.cat/BarcelonaSummerSchool\%207.pdf).

Отже, можна спостерігати протиріччя між широкими можливостями сучасних комп'ютерних засобів, зокрема середовища $\mathrm{R}$ щодо аналізу демографічних процесів та недостатністю х використання у курсах з демографії для студентів-соціологів.

Мета статті: проаналізувати можливості сучасних комп'ютерних засобів щодо аналізу демографічних даних 3 метою навчання майбутніх соціологів, обгрунтувати використання середовища $\mathrm{R}$ як одного 3 інструментів такого аналізу, відібрати необхідні для цього пакети $\mathrm{R}$, презентувати приклади навчання студентів комп'ютерному аналізу демографічних даних шляхом поєднання електронних таблиць, статистичного пакету SPSS, середовища R. 


\section{2. РЕЗУЛЬТАТИ ДОСЛІДЖЕННЯ}

Аналіз наукових джерел [2]-[4] показав, що демографічна статистика використовує арсенал методів загальної теорії статистики, але й власні, оригінальні методи. Стан і склад населення, вивчаються загальними для статистичної науки способами, а вивчення демографічних процесів потребує розвитку системи особливих методів, серед яких можна виділити демографічні таблиці, демографічні сітки тощо. Загальна схема вивчення демографічних процесів складається 3 таких етапів: екстенсивний аналіз новоутворених за певний час сукупностей, тобто новонароджених, новопомерлих і т. і.; інтенсивний аналіз, мета якого зіставити новоутворені сукупності 3 існуючим населенням; моделювання кожного процесу; їх синтез під час моделювання населення в цілому [2, с.121].

Отже, під час аналізу даних демографічних досліджень майбутні соціологи мають застосовувати загальні статистичні методи аналізу даних, які вони вже вивчали в рамках курсів з кількісних методів аналізу даних дослідження. Ці методи мають комп'ютерну реалізацію в електронних таблицях Excel у вигляді статистичних функцій, стандартних діаграм, Пакету аналізу. Статистичний пакет SPSS, який є стандартом у галузі обробки даних у соціальних науках, містить описову статистику, кореляційний i регресійний аналіз, широкий перелік методів багатовимірного аналізу тощо, те ж був предметом вивчення в курсах, що передували вивченню демографії. Тому в навчанні студентів-соціологів аналізу демографічних процесів і структур пропонуємо спиратися на ці комп'ютерні середовища, розширивши їх за рахунок вільного середовища $R$ [12].

Середовище $\mathrm{R}$ включає функції описової статистики, інструменти для розвідувального аналізу даних, методи багатовимірного аналізу, нейронні мережі, дерева рішень, широкий набір інструментів для візуалізації даних тощо. Функціональність $\mathrm{R}$ може розширюватися за рахунок пакетів, які доступні на сайті CRAN, i які можуть бути написані користувачами-фахівцями різних галузей. Середовище $\mathrm{R}$ розвивається зараз з участю всієї світової спільноти. Ось список з 162 книг, пов'язаних з R (http://www.r-project.org/doc/bib/R-books.html).

Головною перевагою $\mathrm{R}$ у даному випадку вважаємо той факт, що в ньому у вигляді пакетів реалізовані специфічні для демографії методи аналізу, зокрема демографічні таблиці, демографічні сітки, демографічні коефіцієнти тощо.

Аналіз наукових джерел [5]-[15], власний досвід викладання дозволяє виділити список пакетів, які доцільно використовувати для навчання студентів обробки даних демографічної статистики (табл.1).

Таблиия 1

Пакети R, які доцільно використовувати для навчання студентів аналізу демографічних даних

\begin{tabular}{|c|c|}
\hline Назва пакету & Короткий зміст \\
\hline demography & $\begin{array}{l}\text { Функції для загальних розрахунків, що використовуються в } \\
\text { демографії: побудова таблиць смертності, моделювання Лі- } \\
\text { Картера; аналіз функціональних даних щодо показників } \\
\text { смертності, показників народжуваності, міграцій; стохастичного } \\
\text { прогнозування }\end{array}$ \\
\hline pyramid & Побудова популяційної піраміди \\
\hline ggplot2 & Візуалізація, інтерактивні графіки \\
\hline $\begin{array}{c}\text { choroplethr, } \\
\text { choroplethrMaps }\end{array}$ & 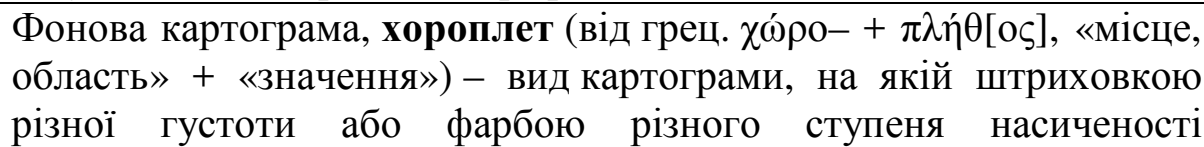 \\
\hline
\end{tabular}




\begin{tabular}{|c|l|l|}
\hline & $\begin{array}{l}\text { зображують інтенсивність будь-якого показника в межах } \\
\text { територіальної одиниці }\end{array}$ \\
\hline acs & $\begin{array}{l}\text { Пошук таблиць у даних переписів у США. Завантаження, } \\
\text { опрацьовування даних American Community Survey та даних } \\
\text { переписів }\end{array}$ \\
\hline $\begin{array}{c}\text { census, } \\
\text { census2010 }\end{array}$ & $\begin{array}{l}\text { Опрацьовування даних останніх двох переписів США (2000 р. та } \\
\text { 2010 р.) }\end{array}$ \\
\hline LexisPlotR & $\begin{array}{l}\text { Сітка Лексіса (графічне зображення сукупностей людей і подій у } \\
\text { іх житті) }\end{array}$ \\
\hline RJSONIO & Перетворення даних різних типів \\
\hline censusapi & $\begin{array}{l}\text { Використання даних переписів США, отримання власного АРI } \\
\text { для доступу до бази даних переписів США }\end{array}$ \\
\hline Кр & Креслення просторових полігонів для даних GADM \\
\hline ggmap & Просторові карти \\
\hline
\end{tabular}

У нагоді для викладача також стануть деякі вбудовані в R масиви демографічних даних різних країн (табл.2).

Таблиия 2

Вбудовані масиви демографічних даних

\begin{tabular}{|c|l|}
\hline Назва масиву & \multicolumn{1}{|c|}{ Зміст } \\
\hline uspop & Популяція США за даними переписів з 1790-1970 pp. \\
\hline fr.mort & База даних смертності Франції \\
\hline aus.ft & База даних фертильності жінок Австралії \\
\hline
\end{tabular}

Дані демографічної статистики по різних країнах можна знайти в світових базах смертності, плідності, даних Держкомстату України, європейської статистики.

Розглянемо в рамках цієї статті два приклади лабораторних робіт 3 аналізу демографічних структур і процесів.

Перший приклад стосується побудови статево-вікової піраміди населення України. Як відомо, віково-статеві піраміди є діаграмами, на яких кількість людей кожного віку або їх частка у населенні у відсотках зображується горизонтальною смугою певного масштабу. Смуги розташовуються одна над іншою в порядку збільшення значень віку, у лівій частині діаграми - для чоловіків, у правій - для жінок. Такі піраміди будуються,зазвичай, за п'ятирічними віковими групами, і дозволяють аналізувати типи відтворення населення у різних країнах і регіонах, або порівнювати дані однієї країни в часі.

Порівняємо дані переписів 1959p. та 2001 р. в Україні.

Спочатку знайдемо інформацію про перепис 1959 р. в Україні.

1. Скористаємося адресою бази даних переписів України:

http://database.ukrcensus.gov.ua/MULT/Database/Census/databasetree_uk.asp

2. Оберемо «Статево-віковий склад населення, Розподіл наявного населення за статтю і віковими групами», що відображено на рис.1. 


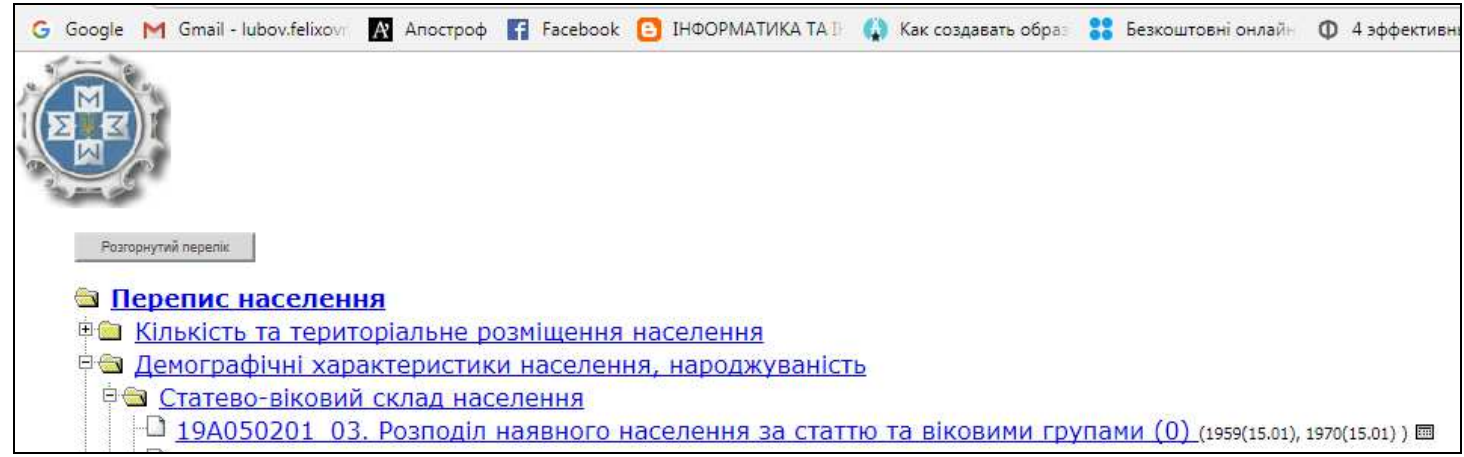

\section{Рис.1. Пошук у базі даних переписів України}

3. У відповідній таблиці 19А050201_03 виберемо дані перепису 1959 р. згідно з рис.2 та натиснемо «Продовжити».

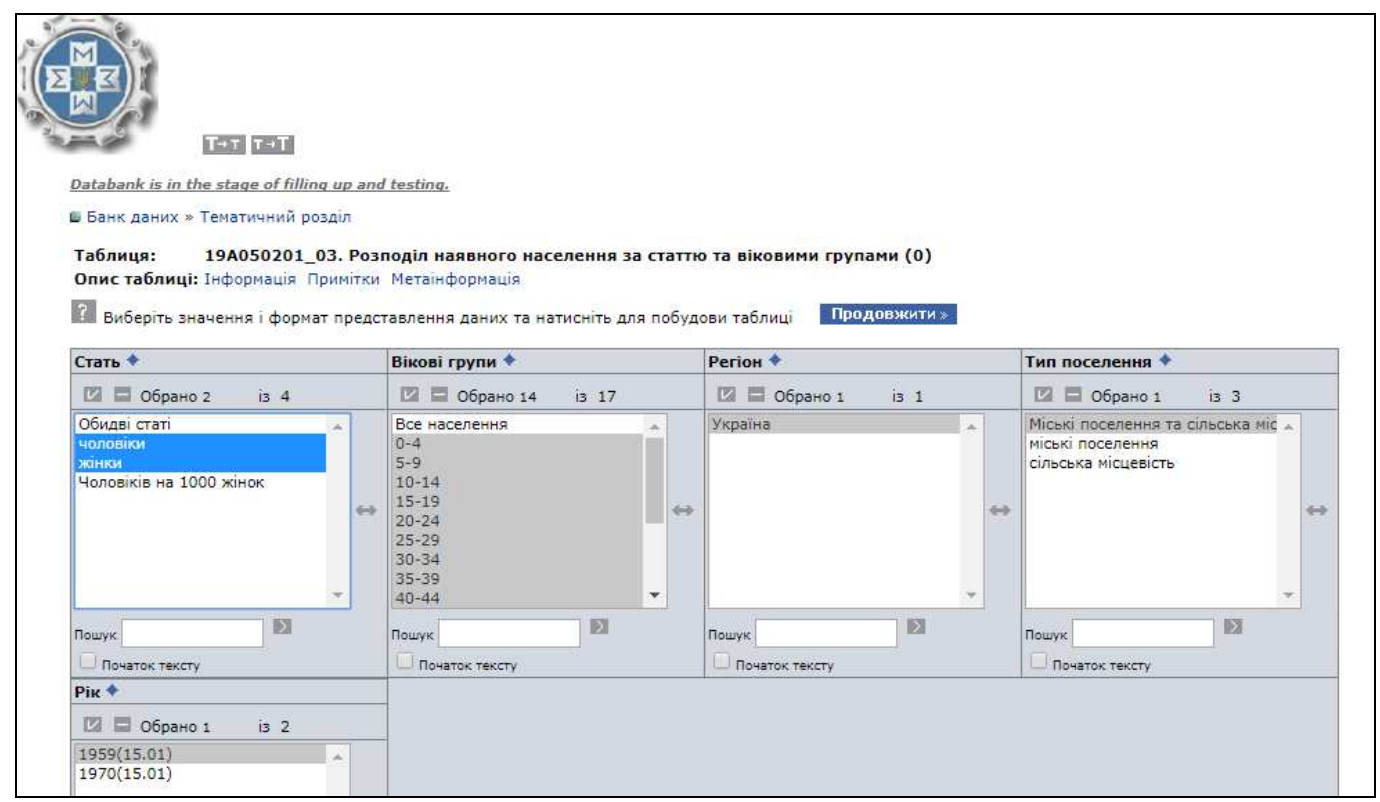

Рис.2. Обирання даних перепису 1959 р. для чоловіків і жінок за віковими групами

4. Отримаємо дані перепису 1959 року в такому вигляді, як показано на рис. 3.

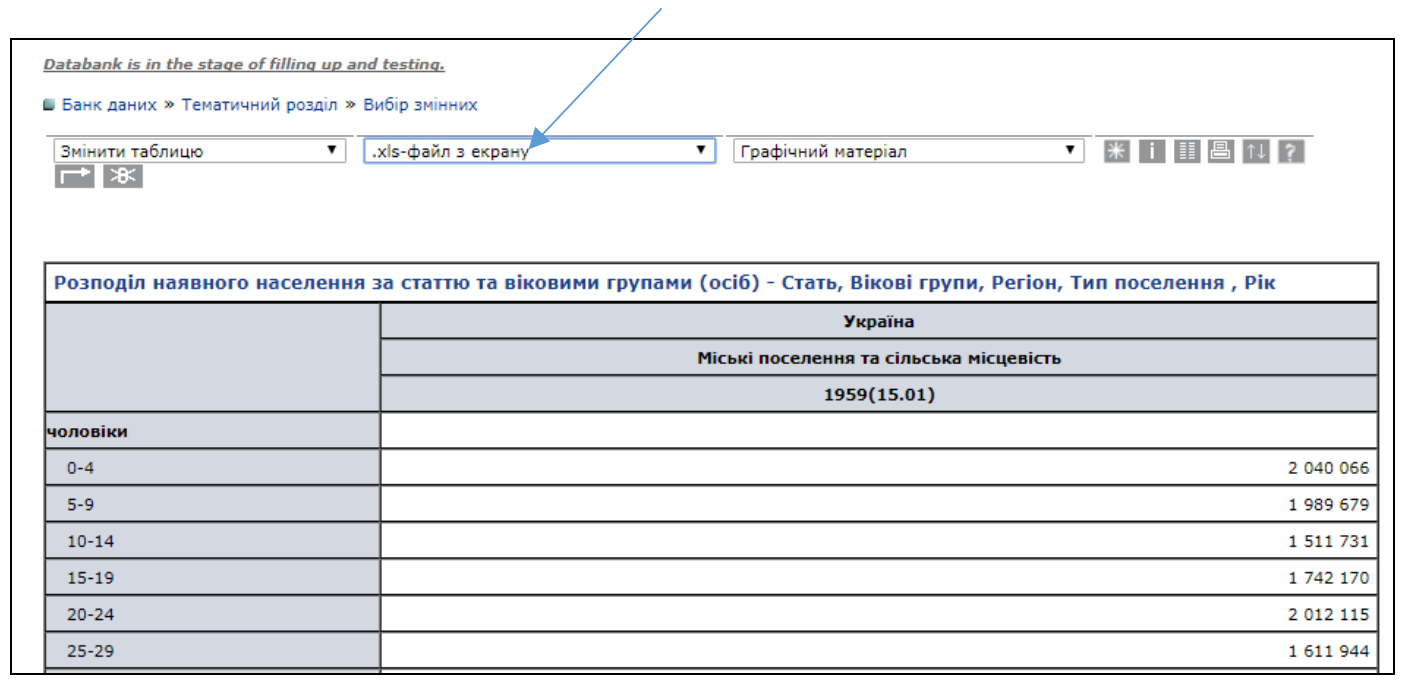

Рис.З.Фрагмент даних про чисельність чоловіків за віковими групами за переписом $1959 \mathrm{p}$. 
5. Збережемо це як файл Excel i побудуємо за цими даними популяційну піраміду в Excel або SPSS (для побудови окремо надаються детальні інструкції).

На наступному кроці студенти знаходять дані останнього перепису в Україні, який відбувався у 2001 p. (http://2001.ukrcensus.gov.ua/publications/\#p2), та порівнюють статево-вікову піраміду населення 1959 та 2001p.

Розглянемо далі два способи побудови популяційної піраміди засобами пакету pyramidy середовищі $\mathrm{R}$.

1 спосіб. Для побудови піраміди ми маємо задати вікові інтервали осіб, а також відсоток чоловіків і жінок для цих вікових інтервалів. Отже, встановивши попередньо пакет pyramid, ми можемо написати таку послідовність команд:

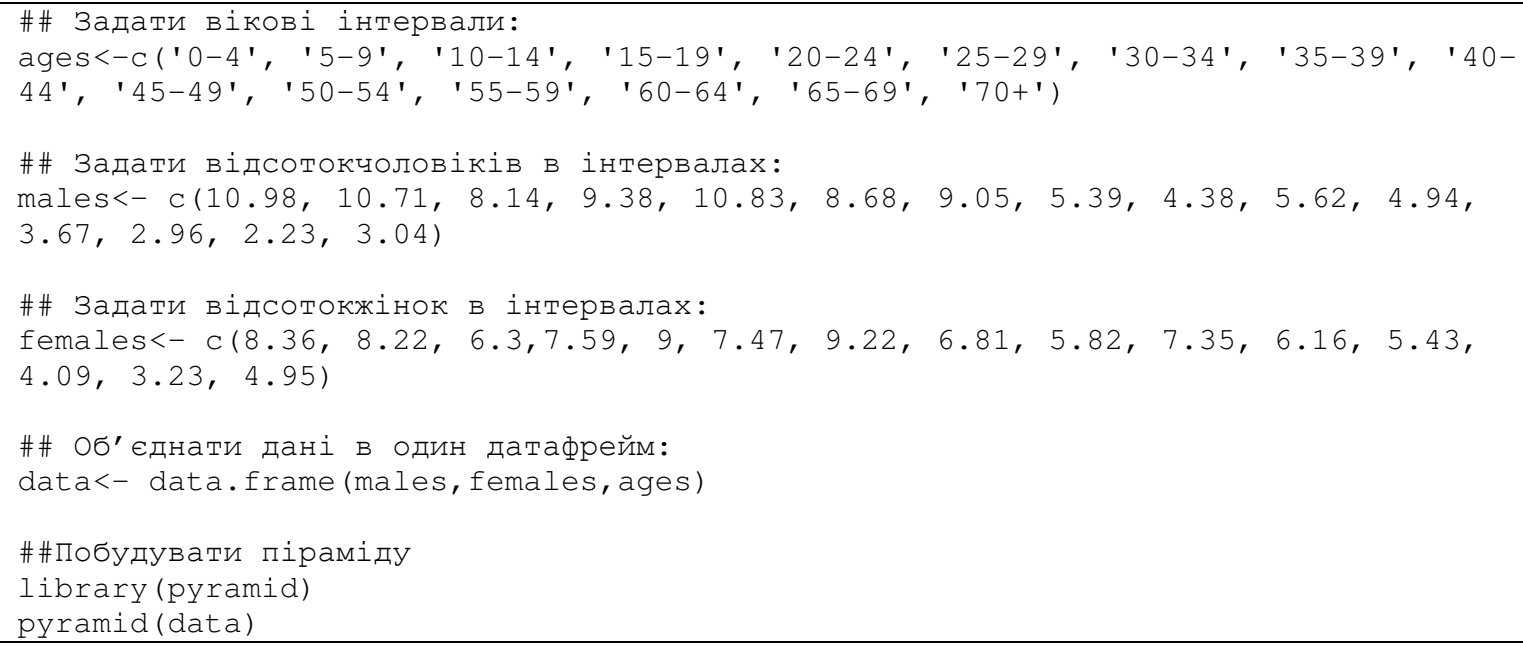

2 спосіб. Попередньо готуємо дані в електронних таблицях Excel i зберігаємо як csv-файлukraine1959R.csv (рис.4).

\begin{tabular}{r|r|r|l|}
\hline \multicolumn{1}{|c|}{ A } & \multicolumn{1}{c|}{ B } & \multicolumn{1}{c|}{ C } \\
\hline 1 & male & female & age \\
\hline 2 & 10,98 & 8,36 & $0-4^{\prime}$ \\
\hline 3 & 10,71 & 8,22 & $5-9^{\prime}$ \\
\hline 4 & 8,14 & 6,30 & $10-14^{\prime}$ \\
\hline 5 & 9,38 & 7,59 & $15-19^{\prime}$ \\
\hline 6 & 10,83 & 9,00 & $20-24^{\prime}$ \\
\hline 7 & 8,68 & 7,47 & $25-29^{\prime}$ \\
\hline 8 & 9,05 & 9,22 & $30-34^{\prime}$ \\
\hline 9 & 5,39 & 6,81 & $35-39^{\prime}$ \\
\hline 10 & 4,38 & 5,82 & $40-44^{\prime}$ \\
\hline 11 & 5,62 & 7,35 & $45-49^{\prime}$ \\
\hline 12 & 4,94 & 6,16 & $50-54^{\prime}$ \\
\hline 13 & 3,67 & 5,43 & $55-59^{\prime}$ \\
\hline 14 & 2,96 & 4,09 & $60-64^{\prime}$ \\
\hline 15 & 2,23 & 3,23 & $65-69^{\prime}$ \\
\hline 16 & 3,04 & 4,95 & $70+^{\prime}$ \\
\hline
\end{tabular}

Рис.4. Дані перепису України 1959 р., підготовлені в електронних таблииях як сsv-файл

У середовищі R використовуємо команди: 


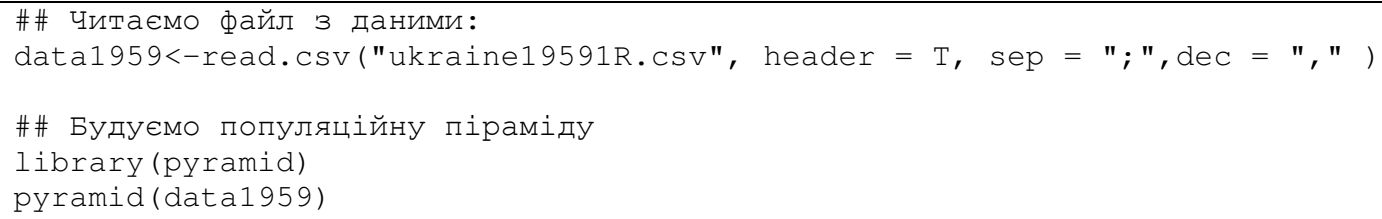

Аналізуємо результати, наведені на рис.5.
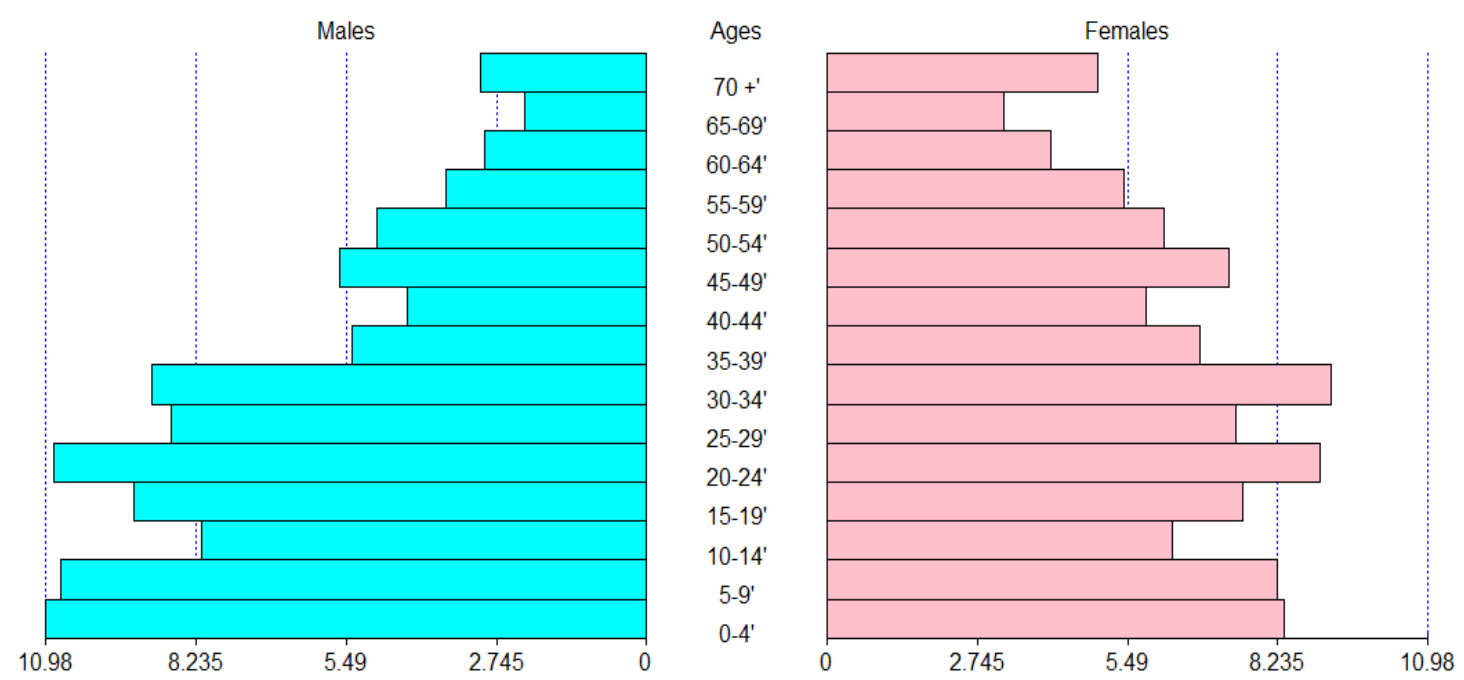

Рис.5. Популящійна піраміда населення України за даними перепису 1959 р. (у \%) [16], побудована в $R$

Зауважимо, що в ході розробленого нами практикуму студенти також будують такі піраміди за допомогою стандартних діаграм в Excel i конструктора діаграм пакету SPSS.

Другий приклад призначений для ілюстрації розрахунків коефіцієнтів демографічного навантаження. Мета цієї роботи:надати досвід розрахування коефіцієнтів демографічного навантаження на прикладі України в середовищах Excel, SPSS, R.

У ході цієї роботи студенти знайомляться з демографічним паспортом населення України (рис. 6), (http://database.ukrcensus.gov.ua/MULT/Dialog/statfile_c_files/ pasport.files/pasport/00_uk.htm\#0202).

\begin{tabular}{|l|l|l|l|l|l|l|l|l|l|l|}
\hline Регіон & \multicolumn{1}{|c|}{ Україна } \\
\hline Рік & $\mathbf{2 0 0 8}$ & $\mathbf{2 0 0 9}$ & $\mathbf{2 0 1 0}$ & $\mathbf{2 0 1 1}$ & $\mathbf{2 0 1 2}$ & $\mathbf{2 0 1 3}$ & $\mathbf{2 0 1 4}$ & $\mathbf{2 0 1 5}$ & $\mathbf{2 0 1 6}$ & $\mathbf{2 0 1 7}$ \\
\hline Міські поселення та сільська місцевість \\
\hline У віці 0-14 років
\end{tabular}




\begin{tabular}{|l|l|l|l|l|l|l|l|l|l|l|l|}
\hline \multicolumn{2}{|l}{ віці 15-64 роки } \\
\hline Обидві статі & $\begin{array}{l}3218451 \\
4\end{array}$ & $\begin{array}{l}3216979 \\
5\end{array}$ & 32130170 & $\begin{array}{l}3213696 \\
8\end{array}$ & $\begin{array}{l}3199331 \\
1\end{array}$ & $\begin{array}{l}3184677 \\
6\end{array}$ & $\begin{array}{l}3160637 \\
4\end{array}$ & $\begin{array}{l}2963471 \\
0\end{array}$ & $\begin{array}{l}2932772 \\
4\end{array}$ & $\begin{array}{l}2901183 \\
5\end{array}$ \\
\hline чоловіки & 1543031 & 1541000 & 15390314 & $\begin{array}{l}1539087 \\
5\end{array}$ & $\begin{array}{l}1533029 \\
4\end{array}$ & $\begin{array}{l}1527711 \\
2\end{array}$ & $\begin{array}{l}1517225 \\
9\end{array}$ & $\begin{array}{l}1424974 \\
9\end{array}$ & $\begin{array}{l}1411674 \\
5\end{array}$ & $\begin{array}{l}1398075 \\
0\end{array}$ \\
\hline жінки & 1675420 & 1675979 & 16739856 & $\begin{array}{l}1674609 \\
3\end{array}$ & $\begin{array}{l}1666301 \\
7\end{array}$ & $\begin{array}{l}1656966 \\
4\end{array}$ & $\begin{array}{l}1643411 \\
5\end{array}$ & $\begin{array}{l}1538496 \\
1\end{array}$ & $\begin{array}{l}1521097 \\
9\end{array}$ & $\begin{array}{l}1503108 \\
5\end{array}$ \\
\hline У віці 65 років і старше \\
\hline
\end{tabular}

Рис. 6. Розподіл постійного населення Украӥни за основними віковими групами (осіб), на початок року

Далі обчислюється демографічне навантаження на покоління батьків в електронних таблицях і представляється так (рис. 7).

\begin{tabular}{|c|c|c|c|c|c|c|c|c|c|c|}
\hline \multirow{2}{*}{$\frac{\text { Регіон }}{\text { Рік }}$} & \multicolumn{10}{|c|}{ Україна } \\
\hline & 2008 & 2009 & 2010 & 2011 & 2012 & 2013 & 2014 & 2015 & 2016 & 2017 \\
\hline Загальне навантаження & 435 & 429 & 425 & 419 & 421 & 425 & 432 & 443 & 452 & 462 \\
\hline $\begin{array}{l}\text { Навантаження особами у віці } \\
\text { 0-14 років }\end{array}$ & 202 & 201 & 202 & 202 & 204 & 208 & 212 & 218 & 221 & 225 \\
\hline $\begin{array}{l}\text { Навантаження особами у віці } \\
65 \text { років і старше }\end{array}$ & 233 & 228 & 223 & 217 & 217 & 217 & 220 & 225 & 231 & 237 \\
\hline
\end{tabular}

Рис. 7. Розраховані коефіцієнти загального навантаження, навантаження дітьми, прабатьками

Результати обчислення візуалізуються у вигляді графіків, які ілюструють зміну демографічного навантаження з часом (рис.8).

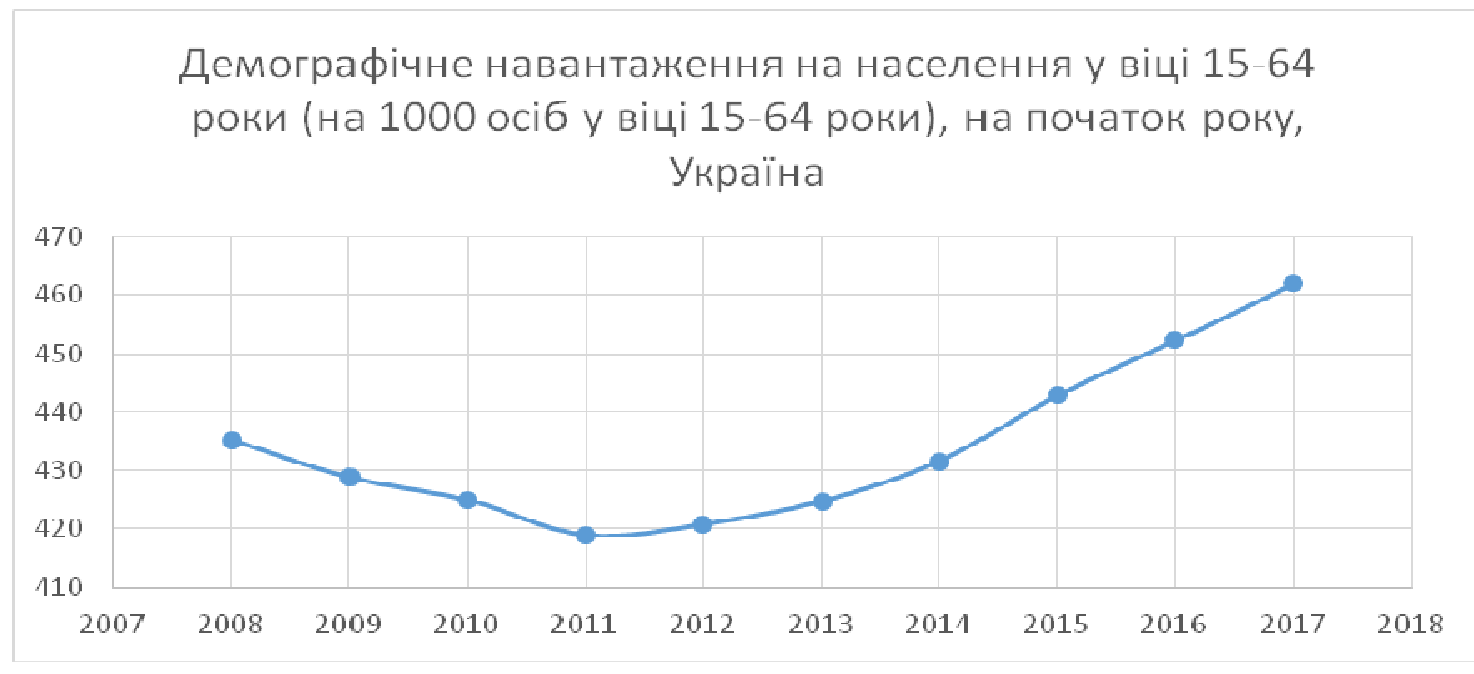

Рис.8. Візуалізація загального демографічного навантаження, Украӥна 
Наступним етапом є представлення тих самих даних в SPSSTa проведення аналогічних розрахунків і побудова графіків. Для цього студенти мають транспонувати дані так, як подано в табл. 3.

Таблиия 3

Транспоновані дані для обчислення коефіціснтів навантаження в SPSS

\begin{tabular}{|c|c|c|c|c|c|c|c|c|c|}
\hline Year & to_14 & m0_14 & f0_14 & t15_64 & m15_64 & f15_64 & t65 & m65 & f65 \\
\hline 2008 & 6501091 & 3336144 & 3164947 & 32184514 & 15430312 & 16754202 & 7506704 & 2531222 & 4975482 \\
\hline 2009 & 6476188 & 3325162 & 3151026 & 32169795 & 15410003 & 16759792 & 7317376 & 2449767 & 4867609 \\
\hline 2010 & 6483560 & 3330609 & 3152951 & 32130170 & 15390314 & 16739856 & 7168862 & 2386144 & 4782718 \\
\hline 2011 & 6495990 & 3338373 & 3157617 & 32136968 & 15390875 & 16746093 & 6965221 & 2303368 & 4661853 \\
\hline 2012 & 6531531 & 3358132 & 3173399 & 31993311 & 15330294 & 16663017 & 6928440 & 2288286 & 4640154 \\
\hline 2013 & 6620598 & 3405479 & 3215119 & 31846776 & 15277112 & 16569664 & 6905318 & 2280153 & 4625165 \\
\hline 2014 & 6710689 & 3453718 & 3256971 & 31606374 & 15172259 & 16434115 & 6928831 & 2292311 & 4636520 \\
\hline 2015 & 6449171 & 3319634 & 3129537 & 29634710 & 14249749 & 15384961 & 6675780 & 2218443 & 4457337 \\
\hline 2016 & 6494293 & 3343782 & 3150511 & 29327724 & 14116745 & 15210979 & 6768862 & 2257354 & 4511508 \\
\hline 2017 & 6535536 & 3365550 & 3169986 & 29011835 & 13980750 & 15031085 & 6867534 & 2298280 & 4569254 \\
\hline
\end{tabular}

Для створення відповідного файлу в SPSS змінні треба описати (рис.9), перенести відповідні дані.

\begin{tabular}{|c|c|c|c|}
\hline & Name & Type & \multirow{13}{*}{$\begin{array}{l}\text { Рік } \\
\text { Населення віком 0-14 років } \\
\text { Чоловіки віком 0-14 років } \\
\text { Жінки0-14 років } \\
\text { Населення віком 15-64 роки } \\
\text { Чоловіки 0-14 років } \\
\text { Жінки0-14 років } \\
\text { Населення старше } 65 \text { років } \\
\text { Чоловіки 65+ } \\
\text { Жінки 65+. } \\
\text { Коефіцієнт загального навантаження } \\
\text { Коефіцієнт навантаження дітьми } \\
\text { Коефіцієнт навантаження прабатьками }\end{array}$} \\
\hline 1 & Year & Numeric & \\
\hline 2 & t0_14 & Numeric & \\
\hline 3 & m0_14 & Numeric & \\
\hline 4 & f0_14 & Numeric & \\
\hline 5 & t15_64 & Numeric & \\
\hline 6 & m15_64 & Numeric & \\
\hline 7 & f15_64 & Numeric & \\
\hline 8 & t65 & Numeric & \\
\hline 9 & m65 & Numeric & \\
\hline 10 & f65 & Numeric & \\
\hline 11 & nt & Numeric & \\
\hline 12 & n0_14 & Numeric & \\
\hline 13 & n65 & Numeric & \\
\hline
\end{tabular}

Puс. 9. Опис змінних уSPSS

Далі можна розрахувати загальний коефіцієнт навантаження за допомогою меню Transform, ComputeVariable(рис.10). 


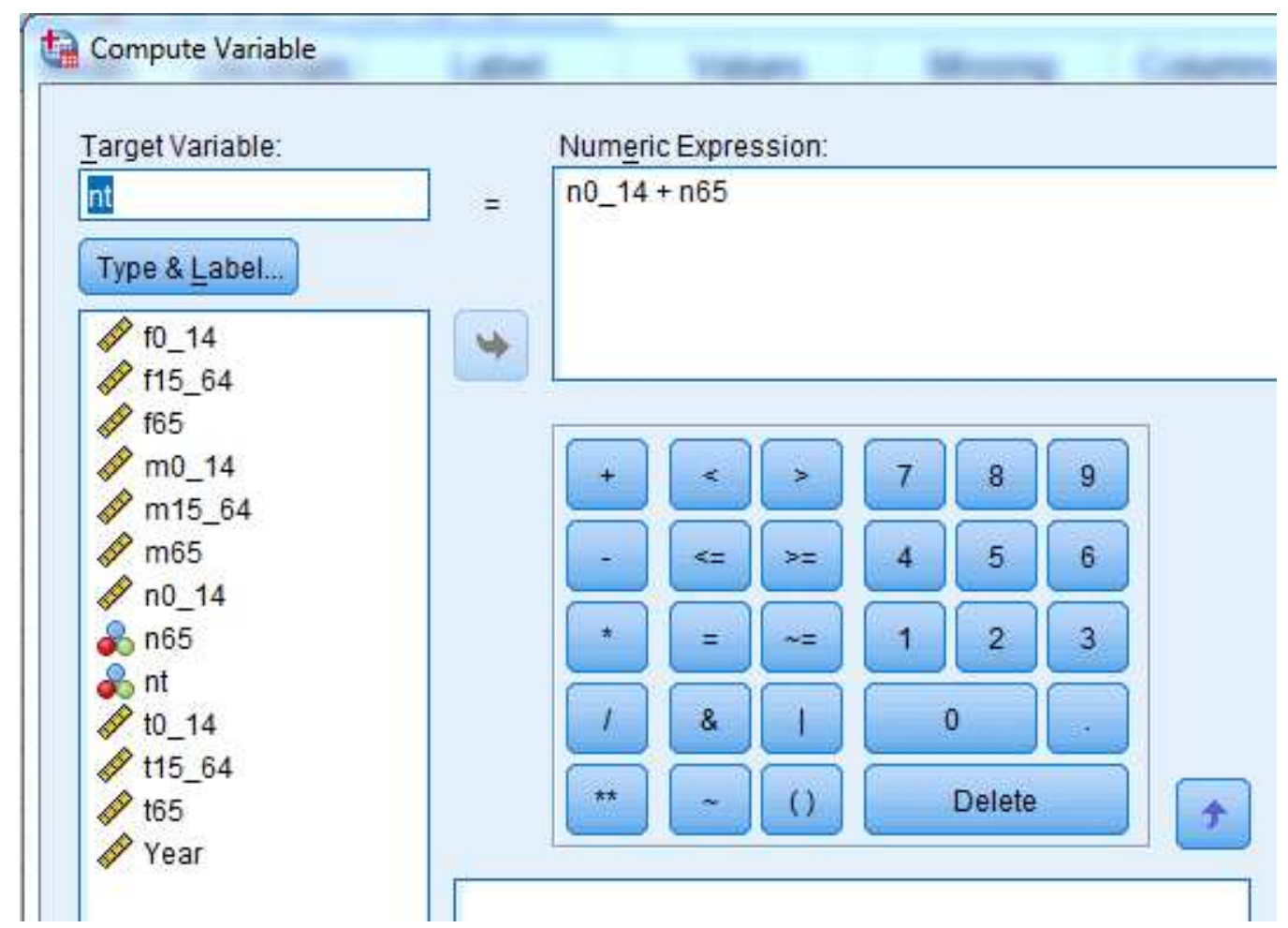

Рис.10. Розрахунки коефіцієнтів навантаження

Для побудови графіка використовуються Graphs, LegacyDialogs (рис. 11).

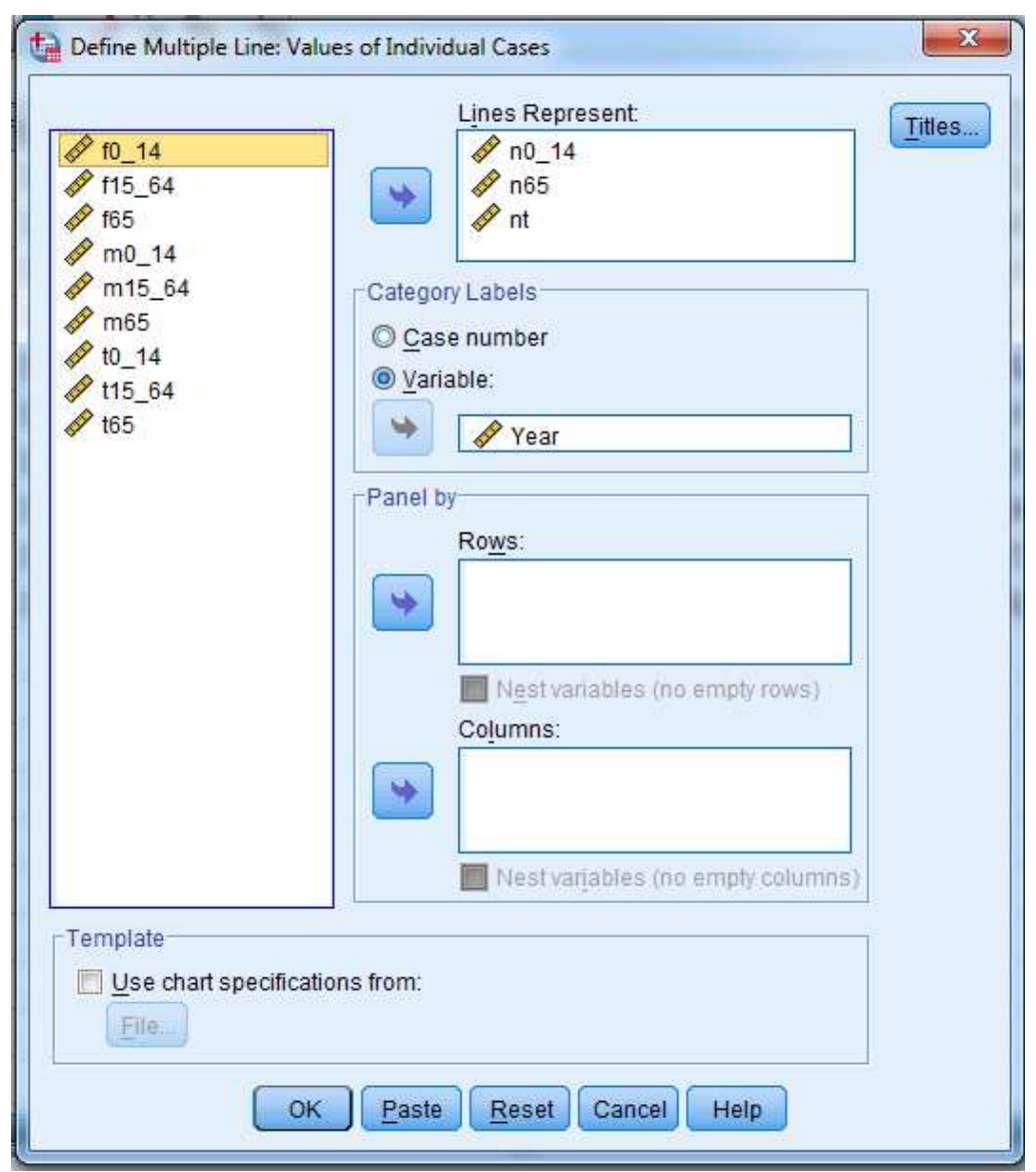




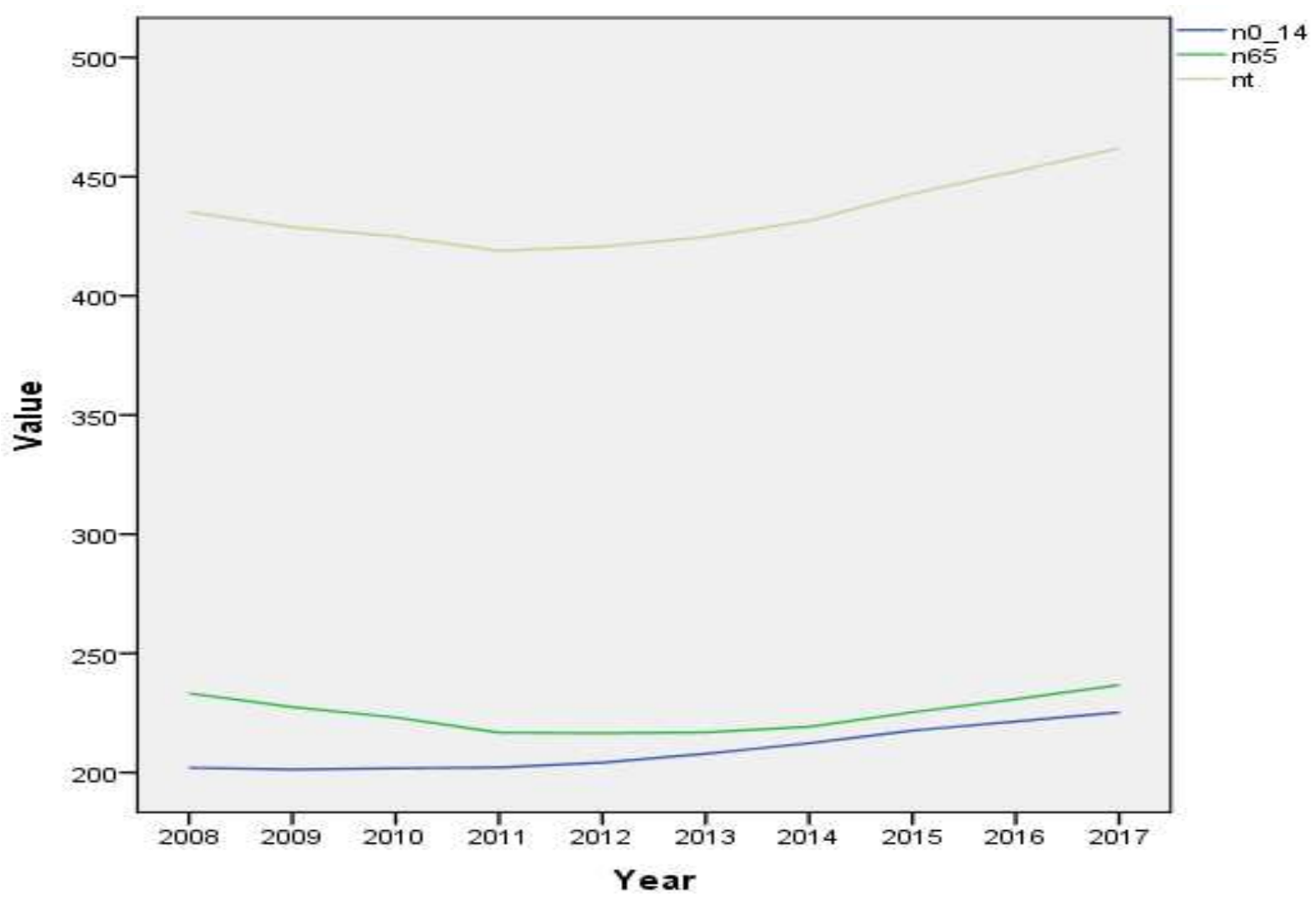

Pис.11. Побудова графіка в SPSS

Наприкінці цього етапу студенти зберігають файл у форматі csv 3 ім'ям nUkraineInput.csv для подальшої роботи в середовищі R.

$\mathrm{V}$ середовищі R спочатку треба прочитати файл з даними (він має бути в поточному каталозі R)

data1<- read.csv("nUkraineInput.CSV", header $=T, \operatorname{sep}=" ; ", \operatorname{dec}=$ ", " )

Щоб з’ясувати структуру даних, доцільно переглянути перші 3 рядки :

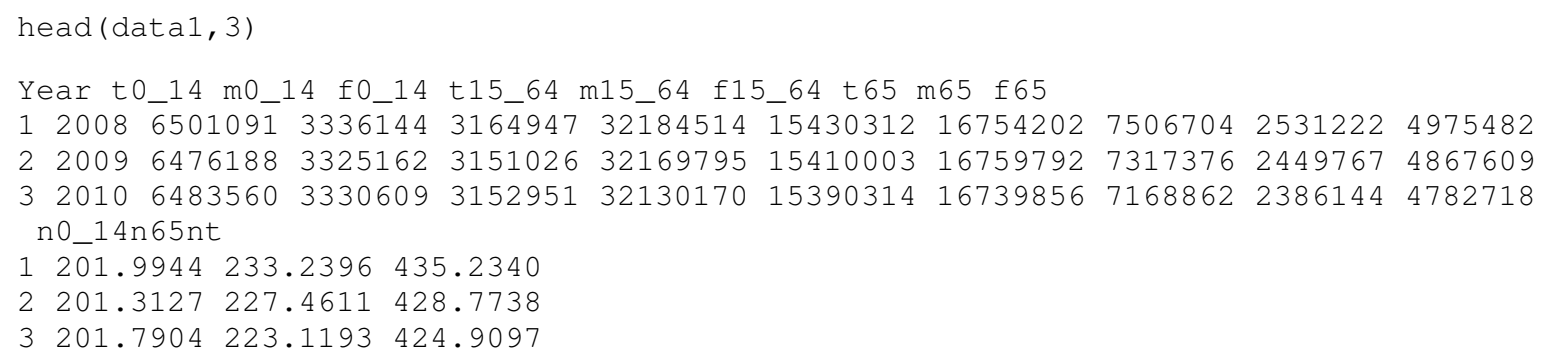

А потім обчислити коефіцієнти навантаження такими командами:

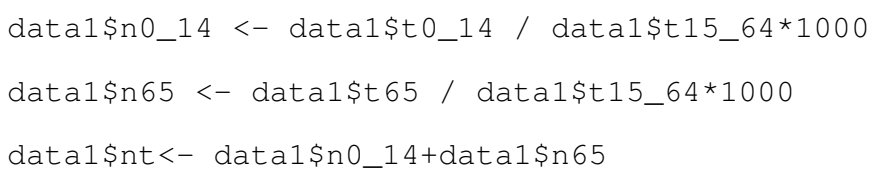

Для побудови графіку базовими засобами R використовується функція plot ( рис. 


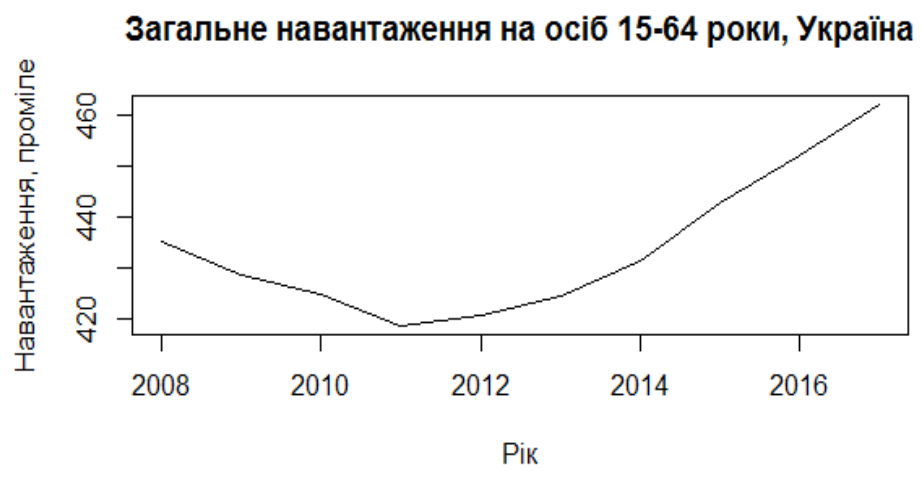

Рис. 12. Графік загального навантаження, побудований у $R$

Як узагальнююче завдання студентам пропонується порівняти отримані дані 3 класифікацією Г. Зунберга [2, с.51] (табл. 4). У рамках цього завдання вони мають використовувати статистичні критерії для порівняння розподілів, зокрема критерій Пірсонах 2.

Таблиия 4

Класифікація вікової структури населення за Г. Зунбергом

\begin{tabular}{|l|c|c|c|}
\hline \multirow{2}{*}{ Вікова група } & \multicolumn{3}{|c|}{ Вікова структура населення, \% } \\
\cline { 1 - 4 } & прогресивна & стаціонарна & регресивна \\
\hline Діти & 40 & 27 & 20 \\
\hline Батьки & 50 & 50 & 50 \\
\hline Прабатьки & 10 & 23 & 30 \\
\hline Разом & 100 & 100 & 100 \\
\hline
\end{tabular}

Розроблене методичне забезпечення 3 навчання студентів-соціологів аналізу демографічних даних містить лекції-презентації з основ роботи в середовищі $\mathrm{R}$ та $\mathrm{R}$ Studio; лабораторні роботи (коротка теорія, детальні інструкції до виконання, контрольні запитання, завдання до самостійної роботи); масиви даних, які додаються до кожної роботи. Більшість робіт побудована так, що студенти знаходять дані, обчислюють демографічні коефіцієнти в Excel, SPSS, R та візуалізують отримані результати за допомогою різного роду графіків, а потім їх порівнюють й інтерпретують.

Теми лабораторних робіт включають такі:

- Побудова популяційної піраміди засобами Excel, SPSS, R.

- Аналіз демографічних даних засобами R.

- Дослідження даних перепису CША в середовищіR.

- Обчислення коефіцієнтів навантаження прабатьками та дітьми.

- Дослідження структури сімей різних країн.

- Національний та етнічний склад населення.

- Статистика зайнятості та безробіття.

- Розрахунки в таблицях дожиття.

- Дослідження даних бази смертності.

- Використання пакету demography середовища R.

- Побудова сітки Лексіса засобами R. 
- Розрахунок показників плідності. Аналіз даних міжнародних баз даних плідності.

- Статистика шлюбності та розлучуваності.

- Обчислення та візуалізація чистої та валової міграції (Excel, SPSS, R.).

У ході робіт студенти реєструються в світових базах смертності та плідності, отримують власне API для доступу до даних переписів США, працюють 3 даними статистики населення України.

Як заключне заняття пропонуємо студентам-соціологам роботу 3 вільним сервісом Gapminder (рис. 13). Gapminder-незалежна шведська установа, яка випускає безкоштовні навчальні ресурси, спрямовані на покращання розуміння світу на основі надійної статистики; вона співпрацює з університетами, ООН, державними установами та неурядовими організаціями. Метою фундації Gapminder $\epsilon$ «сприяння сталому глобальному розвитку та досягнення Цілей тисячоліття ООН зі збільшення використання і розуміння статистичних даних та іншої інформації про соціальний, економічний та екологічний розвиток на місцевому, національному та глобальному рівнях» [17].

Cервіс Gapminder (рис. 14) включає набор інструментів під загальною назвою «Playwithdata» бульбашкову діаграму, карти, ранжування, тренди, вікові піраміди; усі вони дозволяють отримати динамічну візуалізацію обраного демографічного показника (залежно від дослідницького питання) за країнами та континентами в часі (від 1800 до 2015 р.). Так, для категорії «освіта» можна порівнювати академічні досягнення, грамотність, гендерну рівність, середню кількість років навчання, відсоток тих, хто закінчив школу і т. i.

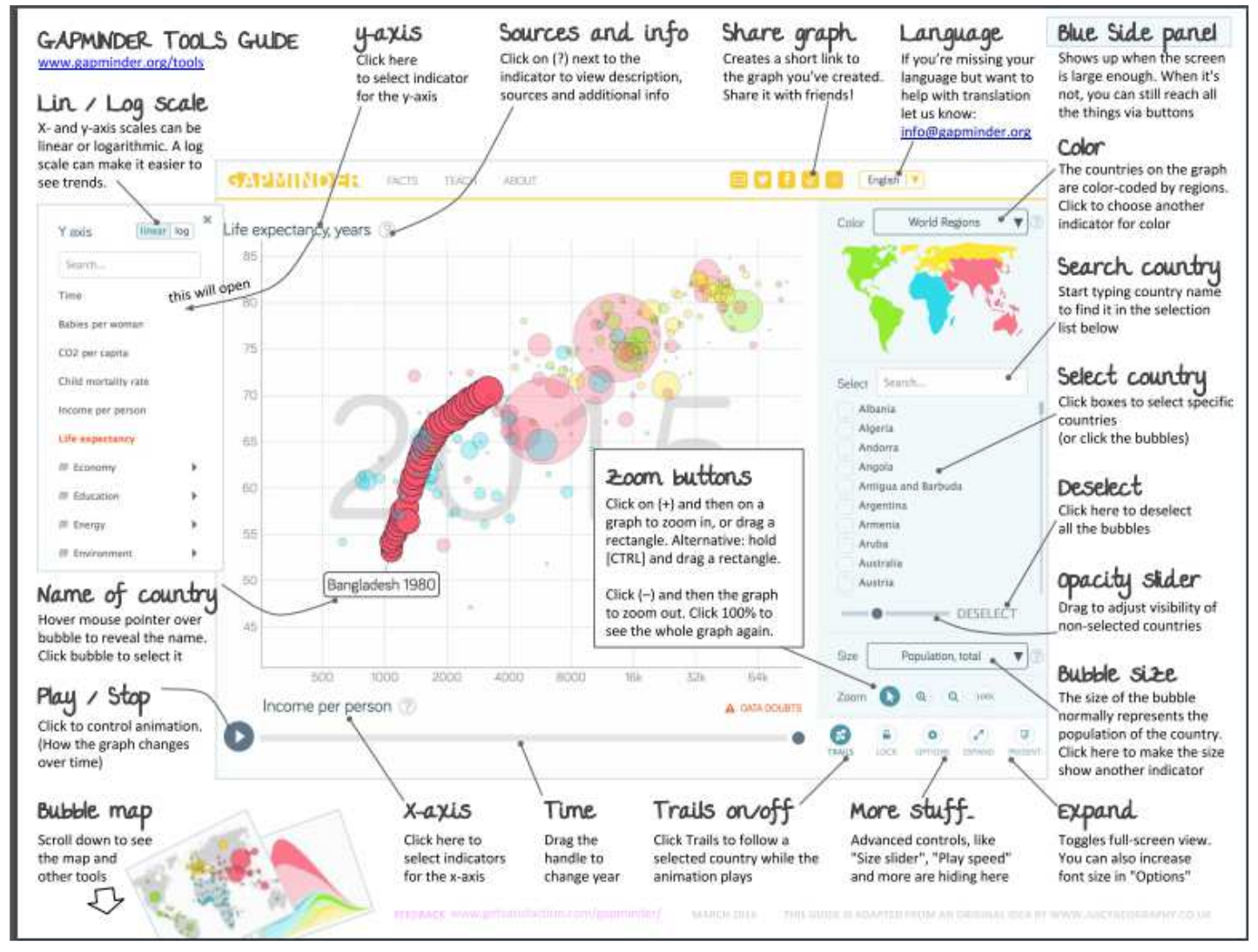

Рис.13. Інструкиія для роботи із сервісом Gapminder 
Зауважимо, що сервіс має дружній інтерфейс, робота 3 ним викликала зацікавленість студентів, які будували популяційні піраміди, порівнювали демографічні показники різних країн у динаміці, створювали рейтинги країн і регіонів за різними показниками, ставили власні дослідницькі запитання й відшукували на них відповідь, вивчали DollarStreet, інтерактивне відображення світу як вулиці, де номер на вулиці відповідає щоденному доходу на людину в сім’ї.
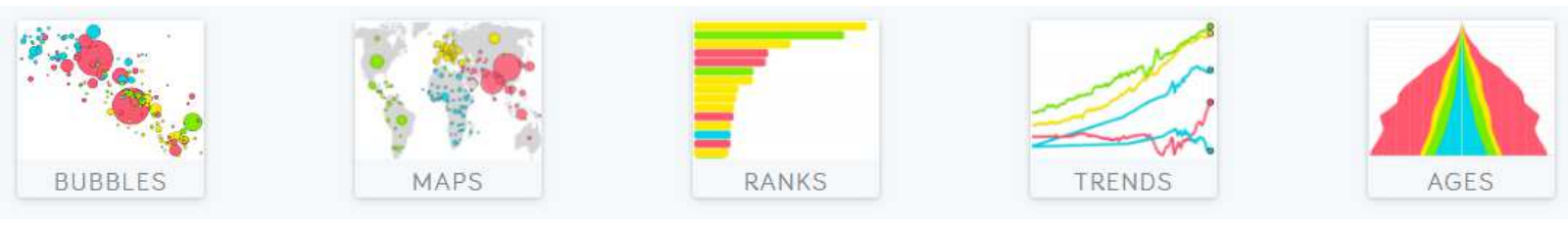

Pис. 14. Інструменти Gapminder: бульбашкові діаграми, карти, ранжування, тренди, вікові піраміди

Часткова відповідь на дослідницьке запитання: «Який тип відтворення населення притаманний різним континентам світу?» представлена на рис.15. Вона стосується Африки й отримана за допомогою інструменту AGES (вікова піраміда).

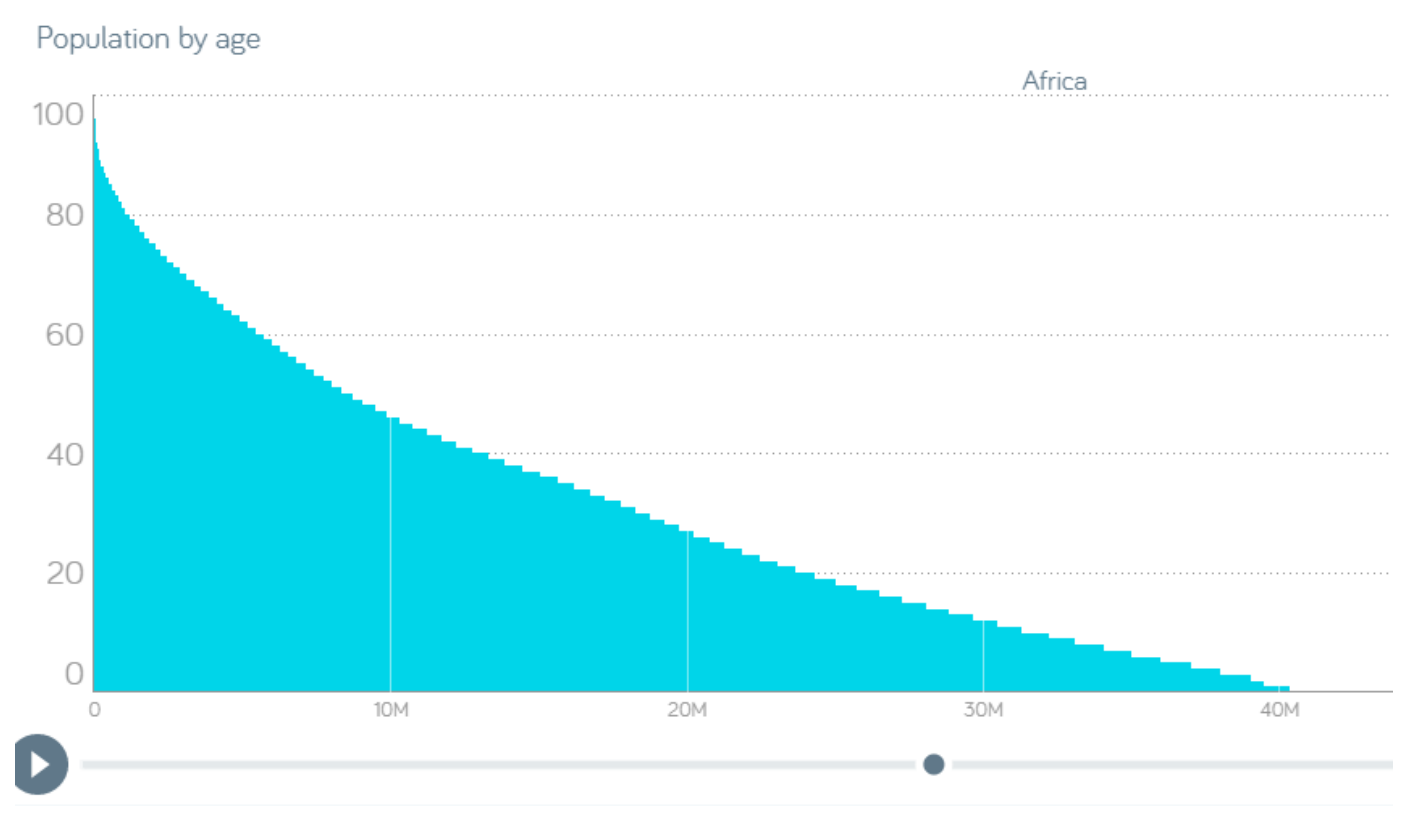

Рис. 15. Вікова піраміда населення Африки, побудована за допомогою інструмента «AGES» Gapminder

На заняттях і в самостійній роботі можна використовувати і низку інших проектів, які пропонує Gapminder, а саме: Bсесвітній розподіл доходів, що містить інтерактивне відображення статистичних даних про розподіл доходів домашніх господарств у Бангладеш, Бразилії,Індії, Індонезії, Китаї, Нігерії, Пакистану, США, Японії і світу (1970-1998); Тенденції розвитку людського потенціалу 2003, тематичну анімовану презентацію для Доповіді про розвиток людства 200; Всесвітню діаграму здоров'я 2001, яка відображає розвиток охорони здоров'я для всіх країн світу 3 часовими рядами для 35 показників. 


\section{3. ВИСНОВКИ ТА ПЕРСПЕКТИВИ ПОДАЛЬШИХ ДОСЛІДЖЕНЬ}

У сучасному глобалізованому цифровому світі зростає важливість підготовки майбутніх соціологів у галузі демографії й демографічної статистики із застосуванням нових комп'ютерних засобів і технологій. З'ясовано, що демографічна статистика використовує загальний арсенал статистичних методів для вивчення складу і стану населення та специфічні методи для вивчення демографічних процесів, зокрема демографічні таблиці, демографічні сітки тощо. Отже, у ході навчання майбутніх соціологів комп'ютерному аналізу демографічних процесів i структур доцільно спиратися на їх попередню підготовку щодо кількісних методів і знайомство зі статистичним пакетом SPSS та електронними таблицями Excel. Пропонується розширити цей перелік за рахунок середовища $R$, у якому реалізовані не лише загальні статистичні методи, а й специфічні, саме для демографії. Як свідчить наш досвід,можливості середовища $\mathrm{R}$ дозволяють 3 успіхом застосовувати його для навчання студентів аналізу демографічних даних. Серед пакетів $\mathrm{R}$, які доцільно використовувати для обробки демографічної інформації,d emography, piramid, ggplot2,choroplethr, choroplethrMaps, acs, census, census2010, LexisPlotR, censusapi та ін. Зауважимо, що демографічні пакети працюють лише з останніми версіями RiRStudio, та 3 версією Windows 7 та вище. Оболонка R Studio полегшує процес аналізу даних у R. Використання декількох інструментів -Excel, SPSS, R- уможливлює порівняння результатів аналізу тих самих даних та їх візуалізації у різних середовищах з метою поглибленого розуміння студентами процесів, що вивчаються. Урізноманітнювати процес навчання аналізу демографічних процесів та мотивувати студентів на самостійний пошук допоможе вільно поширюване програмне забезпечення Gapminder, що дозволяє формулювати дослідницькі питання 3 демографічного аналізу й відшукувати на них візуалізовану відповідь як онлайн, так і офлайн, порівнюючи в часі країни і континенти.

Напрямки подальшого дослідження ми пов'язуємо 3 розробкою навчальнометодичного забезпечення 3 демографічного прогнозування в середовищі $\mathrm{R}$, поглибленого вивчення побудови просторових карт і створення звітів 3 досліджень засобами R Markdown.

\section{СПИСОК ВИКОРИСТАНИХ ДЖЕРЕЛ}

[1] P. V. Voss. «Demography as a Spatial Social Science». Population Research and Policy Review,№26,p.457-476, 2007.

[2] С. Г. Стеценко, Демографічна статистика, К., Вища школа, 2005.

[3] І. М. Прибиткова, Основи демографії, К., «АртЕк», 1995.

[4] 3.О. Пальян, Демографічна статистика,К., КНЕУ, 2003.

[5] J. Fox, R.Andersen. «Using the $r$ statistical computing environment to teach social statistics courses».[Електронний ресурс]. Режим доступу: https://r-forge.r-project.org/R/?group_id=328.

[6] R. S. Bivand, E. Pebesma, V. Gómez-Rubio, Applied Spatial Data Analysis with R, New York, 2013.

[7] A. Lamstein. Exploring the World with Choroplethr [Електронний ресурс]. Режим доступу: https://www.slideshare.net/main/private_slideshow?path_to_redirect_at=https $\% 3 \mathrm{~A} \% 2 \mathrm{~F} \% 2 \mathrm{Fwww}$.slidesh are.net $\% 2$ Farilamstein $\% 2$ Fexploring-the-world-with-choroplethr-febru.

[8] R. Hyndman «Forecasting time series using R». [Електронний ресурс]. Режим доступу: https://robjhyndman.com/seminars/melbournerug/.

[9] Zack W. Almquist. «US Census Spatial and Demographic Datain R:The UScensus2000 Suite of Packages», Journal of Statistical Software, November 2010, Vol. 37, Issue 6. [Електронний ресурс]. Режим доступу: http://www.jstatsoft.org256.

[10] US census 2010. [Електронний ресурс]. Режим доступу: http://r.adu.org.za/web/packages/UScensus2010/UScensus2010.pdf. 
[11] C. G. Camarda

[Електронний

pecypc].

Режим

доступу: https://sites.google.com/site/carlogiovannicamarda.

[12] R Development Core Team (2010). R: A language and environment for statistical computing. R Foundation for Statistical Computing, Vienna, Austria. ISBN 3- 900051-07-0 [Електронний ресурс]. Режим доступу:http//www.R-project.org.

[13] R-project.org. (2017). R: The R Project for Statistical Computing [Електронний ресурс]. Режим доступу: http://www.R-project.org .

[14] Cran.r-project.org, 2017 [Електронний pecypc]. Режим доступу: https://cran.rproject.org/web/packages/demography/demography.pdf. .

[15] Cran.r-project.org,2017 [Електронний pecypc]. Режим доступу:https://cran.rproject.org/web/packages/LexisPlotR/LexisPlotR.pdf.

[16] Cran.r-project.org,2017. [Електронний pecypc]. Режим доступу:https://cran.rproject.org/web/packages/pyramid/pyramid.pdf.

[17] Перепис населення України [Електронний ресурс]. Режим доступу : http://database.ukrcensus.gov.ua/MULT/Database/Census/databasetree_uk.asp.

[18] Gapminder [Електронний ресурс]. Режим доступу: http://www.gapminder.org/.

[19] Л. Ф. Панченко, Практикум по аналізу данных, Луганск, Изд-во ГУ «ЛНУ имени Тараса Шевченко»,2013.

Матеріал надійшов до редакиії 09.01.2018 p.

\title{
ПОДГОТОВКА БУДУЩИХ СОЦИОЛОГОВ К КОМПЬЮТЕРНОМУ АНАЛИЗУ ДЕМОГРАФИЧЕСКИХ ПРОЦЕССОВ И СТРУКТУР
}

\author{
Панченко Любовь Феликсовна \\ профессор, доктор педагогических наук, профессор кафедры социологии \\ НТУУ «Киевский политехнический институт им. И.Сикорского», г. Киев, Украина \\ ORCID ID 0000-0002-9979-0625 \\ lubov.felixovna@gmail.com
}

\begin{abstract}
Аннотация. В современном глобализованном цифровом мире возрастает важность подготовки будущих социологов в области демографии и демографической статистики, основанной не только на демографических теориях, но и практическом применении новых компьютерных средств и технологий, баз данных и сервисов Интернет. В статье анализируются возможности современных компьютерных средств анализа демографических процессов и структур с целью обучения будущих социологов; обосновывается использование среды $\mathrm{R}$ как инструмента анализа и графического представления демографических данных; презентуется идея обучения студентов компьютерному анализу данных демографических исследований путем совместного использования электронных таблиц Excel, статистического пакета SPSS, среды R, которая иллюстрируется двумя примерами. Первый пример касается построения и сравнения половозрастной пирамиды населения Украины за разные годы и включает поиск соответствующих данных, построение пирамиды стандартными средствами для построения диаграмм Excel; средством SPSS (ChartBuilder, Histogram, PopulationPyramid), c использованием пакета pyramid среды R. Второй пример, посвященный расчетам коэффициентов демографической нагрузки детьми и прародителями, визуализации их динамики, предполагает знакомство с демографическим паспортом населения Украины. В статье представлены разработанное методическое обеспечение по обучению студентовсоциологов анализу демографических данных, которое содержит лекции-презентации по основам работы в среде R и R Studio; лабораторные работы (короткая теория, подробные инструкции для выполнения, контрольные вопросы, задания для самостоятельной работы); массивы данных, которые предлагаются к каждой работе. Анализируются дидактические возможности и пути использования свободного сервиса Gapminder, который включает перечень инструментов под общим названием «Playwithdata» пузырьковую диаграмму, карты, ранжирование, тренды, возрастные пирамиды; все они позволяют получить яркие динамические визуализации избранных демографических показателей (в зависимости от исследовательского вопроса) по странам и континентам во времени, что мотивирует студентов на дополнительный научный поиск.
\end{abstract}


Ключевые слова: компьютерный анализ данных, демографические данные, Excel, SPSS, среда R, информационно-коммуникационные технологии, Gapminder, студенты-социологи.

\title{
TRAINING SOCIOLOGY STUDENTS IN COMPUTER ANALYSIS OF DEMOGRAPHIC PROCESSES AND STRUCTURE
}

\author{
Liubov F. Panchenko \\ Dr. of Pedagogical Sciences, PhD, Professor, Professor of the Department of Sociology \\ National Technical University of Ukraine «Igor Sikorsky Kyiv Polytechnic Institute», Kyiv, Ukraine \\ ORCID ID 0000-0002-9979-0625 \\ lubov.felixovna@gmail.com
}

\begin{abstract}
In the modern era of digital globalization, it is becoming more and more important to train sociology students in the field of demographics and demographic statistics based not only on demographic theories but also on the practical application of the new computer tools and technologies, databases and Internet services. The article analyzes the capabilities of modern computer tools for the analysis of demographic processes and structures in training sociology students; substantiates the use of the $\mathrm{R}$ environment as a tool for analysis and graphical representation of demographic data. It presents the idea of teaching students to perform computer analysis of demographic data using a combination of Excel spreadsheets, SPSS statistical package, $\mathrm{R}$ environment illustrated by two examples. The first example concerns building and comparing the gender-age pyramid of the population of Ukraine at different years and includes searching for the relevant data, building the pyramid using standard diagram building Excel tools, using SPSS tools (Chart Builder, Histogram, Population Pyramid), and using pyramid package of $\mathrm{R}$ environment. The second example relates to calculation of childcare and grandparent care load coefficients, visualizing their dynamics, and includes an introduction to the demographic passport of Ukraine. The article presents the developed methodological support for teaching sociology students to perform demographic data analysis, including presentation-lectures on the fundamental principles of work in $\mathrm{R}$ and $\mathrm{R}$ Studio environment, laboratory works (theory summary, detailed operative instructions, control questions, tasks for students 'independent work); data packages attached to every assignment. The author has analyzed the didactic capabilities of the free Gapminder service that includes the list of the tools titled 'Play with Data', bubble chart, maps, ranking, trends, age pyramids. This provides colorful and dynamic data visualization for chosen demographic criteria (depending on the research objectives) by countries and continents over time that stimulates the students to conduct additional scientific research.
\end{abstract}

Keywords: computer data analysis; demographic data; Excel; SPSS; environment R; information and communication technologies; Gapminder; students-sociologists.

\section{REFERENCES (TRANSLATED AND TRANSLITERATED)}

[1] P.V. Voss. «Demography as a Spatial Social Science». Population Research and Policy Review,№26, p.457-476, 2007. (in English)

[2] S.G. Stecenko, Demographic statistics,K., Higher School Press, 2005. (in Ukrainian)

[3] I.M. Prybytkova, Fundamentals of Demography, K., «ArtEk», 1995. (in Ukrainian)

[4] Z.O. Paljjan, Demographic statistics, K., KNEU, 2003. (in Ukrainian)

[5] J. Fox, R.Andersen. «Using the $r$ statistical computing environment to teach social statistics courses». [Online]. Available:https://r-forge.r-project.org/R/?group_id=328(in English)

[6] R.S.Bivand, E. Pebesma, V. Gómez-Rubio, Applied Spatial Data Analysis with R, NewYork, 2013. (in English)

[7] A.Lamstein. Exploring the World with Choroplethr [Online]. Available: https://www.slideshare.net/main/private_slideshow?path_to_redirect_at=https $\% 3 \mathrm{~A} \% 2 \mathrm{~F} \% 2 \mathrm{Fwww}$.slidesh are.net\%2Farilamstein\%2Fexploring-the-world-with-choroplethr-febru (in English)

[8] R. Hyndman «Forecasting time series using R». [Online]. Available: https://robjhyndman.com/seminars/melbournerug/(in English) 
[9] Zack W. Almquist. «US Census Spatial and Demographic Data in R:The UScensus2000 Suite of Packages», Journal of Statistical Software, November 2010, Vol. 37, Issue 6. [Online]. Available: http://www.jstatsoft.org256 (inEnglish)

[10] US
http://r.adu.org.za/web/packages/UScensus2010/UScensus2010.pdf(in English)

[Online]. Available:

[11] C. G.Camarda. [Online]. Available: https://sites.google.com/site/carlogiovannicamarda (in English)

[12] R Development Core Team (2010). R: A language and environment for statistical computing. R Foundation for Statistical Computing, Vienna, Austria. ISBN 3- 900051-07-0, URL http://www.Rproject.org (in English)

[13] R-project.org. (2017). R: The R Project for Statistical Computing. [online] Availableat: http://www.Rproject.org (in English)

[14] Cran.r-project.org, 2017. [Online]. Available: https://cran.rproject.org/web/packages/demography/demography.pdf (in English)

[15] Cran.r-project.org,2017. [Online]. project.org/web/packages/LexisPlotR/LexisPlotR.pdf (in English)

Available:https://cran.r-

] Cran.r-project.org,2017. [Online]. Available:https://cran.r-project.org/web/packages/pyramid/pyramid.pdf (in English)

[17] Ukraine

census. [Online].

Available: http://database.ukrcensus.gov.ua/MULT/Database/Census/databasetree_uk.asp (in Ukrainian)

[18] Gapminder. [Online]. Available: http://www.gapminder.org/ (in English)

[19] L.F.Panchenko,Data analysis practicum,Luhansk, Luhansk Taras Shevchenko National University Press,2013.(in Russian)

\section{$(\mathrm{Cc})$ EY-NC-SA}

This work is licensed under Creative Commons Attribution-NonCommercial-ShareAlike 4.0 International License. 